\title{
Balkanologie
}

Balkanologie Revue d'études pluridisciplinaires

Vol. $16 n^{\circ} 1 \mid 2021$

Au-delà de la "route des Balkans ": mondes sociaux des circulations

\section{Evlad-ı fatihan: Marking Conformability of Balkan Immigrants in Turkey}

Evlad-1 Fatihan: marquer la comformabilité des immigrants des Balkans en Turquie

\section{Elif Becan}

\section{OpenEdition}

\section{Journals}

Electronic version

URL: https://journals.openedition.org/balkanologie/2848

DOI: 10.4000/balkanologie.2848

ISSN: 1965-0582

\section{Publisher}

Association française d'études sur les Balkans (Afebalk)

\section{Electronic reference}

Elif Becan, "Evlad-ı fatihan: Marking Conformability of Balkan Immigrants in Turkey", Balkanologie [Online], Vol. 16 n $^{\circ} 1$ | 2021, Online since 01 June 2021, connection on 03 October 2021. URL: http:// journals.openedition.org/balkanologie/2848 ; DOI: https://doi.org/10.4000/balkanologie.2848

This text was automatically generated on 3 October 2021.

(C) Tous droits réservés 


\title{
Evlad-ı fatihan: Marking Conformability of Balkan Immigrants in Turkey
}

\author{
Evlad-1 Fatihan: marquer la comformabilité des immigrants des Balkans en \\ Turquie
}

Elif Becan

1 Evlad- $\iota$ fatihan (children of conquerors) is a label, supposedly dating back to the thirteenth century ${ }^{1}$. It is mostly used as a self-referent by men of Muslim descent whose parents immigrated from the Balkans to Turkey from the early twentieth century onwards. The current mainstream usage signifies a regional, religious and ethnic identity to legitimize the place of a group in the Republic of Turkey.

2 My encounter with this label took place during my first field study in Balkan homeland associations in Istanbul in 2013. While I was investigating differences between language practices used by the generation that migrated to Turkey and their children, I studied the Gostivarllar Derneği (Gostivar [Macedonia] Association) in the district of Alibeyköy. My interviewees kept invoking evlad-ı fatihan to describe their parents, themselves and their genealogical heritage. My main focus was on "Albanian" migrant populations, and I discovered that even those who defined themselves as "Albanians" of Macedonia also identified themselves as evlad-ı fatihan. But I further observed that only men used this term and that it conveyed a certain image of masculinity. I also noticed that some actors and members of the homeland associations referenced the history of Ottoman conquests in order to legitimize their migration to the Republic of Turkey. I later came across, at the National Library in Ankara, a magazine called Evlad-ı Fatihan, published since 1998 by the Bursa Branch of the Batı Trakyallar Derneği (Western Thracian Association ${ }^{2}$, to which the label served to interpret spatial and historical identifications. Nevertheless, the term is not used in state documents to identify Muslim Balkan immigrants; no trace of it could be found in the Republican National Archives in Ankara. 
3 Naturalization, settlement and assimilation policies enacted by the Turkish state apparatus shaped the individual and collective identification processes of Balkan immigrant populations. The national archives demonstrate that the newcomers were identified as Muslims affiliated to "Turkish culture", "Turkish ascendance" or "Turkish race" during the first half of the twentieth century, ${ }^{3}$ but there was no recognizable link to the label which they invoked. I conducted interviews with thirty-two individuals who proclaimed to be evlad-ı fatihan and made observations mainly in five homeland associations in Istanbul, verifying that this label is used across the Balkan homeland associations. ${ }^{4}$ I therefore questioned its meaning in this very particular context. After looking for its historical origins and the evolutions of its meaning, I wondered what part it had in the state discourse. The absence of reference to this denomination is intriguing and could lead us to question its meaning for those who appropriate it and reveal an integration strategy. However, could those who call themselves evlad-l fatihan form a socially engineered group? Why do some identify with it while others do not? In short, how do we track an identification process?

This research aims to open a discussion on how historical and spatial references were experienced and interpreted by the actors and investigates how the usage of evlad-l fatihan as a label has been conveying an ever-shifting position between otherness and conformity for Turkish speaking as well as bilingual Balkan post-migrants ${ }^{5}$ in Turkey. This research neither analyzes the immigration procedure nor exposes the context in which homeland associations are founded. It should therefore be seen as a circumscribed analysis of one aspect of a self-identification process. ${ }^{6}$ Specifically, it shows how references to Ottoman heritage and to Islam help secure the conformity of post-migrants. Evlad-l fatihan serves to claim that those who are so described are descendants of the conquerors of Rumelia ${ }^{7}$ who have returned to the motherland (anavatan and/or anayurt). Its invocation furthers a claim that they are not immigrants, but members of returning diaspora. During interviews, the legitimacy of this narrative is constructed through the rhetoric of "lost lands".

5 The paper is thus divided into three parts. The first part will lean on the identification process through historical references and outline briefly the administrative categorizations of social signatures (such as language). The second part will demonstrate identification through the spatial references associated with the idea of the "conquest" and will aim at a bottom-up approach that investigates the meaning of evlad- 1 fatihan for those who have appropriated it. Lastly, the third part will draw out the lexical and semantic repertoire through the monthly magazine Evlad-ı Fatihan.

\section{Identification through historical references}

6 Evlad-ı fatihan is an invented tradition which inculcates a sense of identification to "attempt to establish continuity with a suitable historic past." ${ }^{\text {The }}$ appropriation of evlad-ı fatihan by some post-migrants in Turkey demonstrates patterns of a label, produced in a specific local context, to legitimize an ancestral continuity and "[...] extend the old symbolic vocabulary beyond its established limits [...]." original use in the Ottoman Rumelian context has been appropriated to embrace the twentieth-century migration and administrative categorization of Balkan Muslim migrants to the Republic of Turkey. 


\section{Emigration from the Balkans: embodying the official Republican criteria}

Migrations from the Balkans to modern Turkey have occurred in four distinctive periods: after the Balkan Wars (1912-1913) until the beginning of the First World War; during the Interwar period (a time heavily charged with social engineering processes in post-Ottoman space); after the Second World War until the 1960s; and during the wars in Bosnia and Kosovo in the 1990s. The number of immigrants from the Balkans is substantial: estimated nearly 900,000 during the twentieth century. ${ }^{10}$ The majority of those immigrating were Muslims, mostly affiliated to the Sunnite confession, and came from Greece, Bulgaria, Romania, and Albania. A large group, as well as the families of interviewees of this research, came from Serbia, later from the Kingdom of Yugoslavia and then from the Federal Socialist Republic of Yugoslavia between the 1950s and 1960s.

8 In the early years of the Republic of Turkey, especially until the 1940s, the Turkish authorities saw these immigrants as muhacir: participants in Hegira (exodus, migration) in the name of Islam. ${ }^{11}$ Even though the immigrants did not necessarily speak Turkish, they were perceived as Muslims from a former Ottoman space. The criteria of their admission to Turkey were based on religious, historical and spatial credentials of the Empire.

9 The term muhacir referred initially to forcibly displaced Muslims at the end of the Ottoman era, but it subsequently became a legal status at the beginning of the Republican era, especially through the Settlement Law (Iskan Kanunu) of June $1934 .^{12}$ This law marked a clear distinction between the immigration status of Muslim and nonMuslim migrants and equated Islam with Turkishness. Before then, the reception criteria were based on several variables that determined Turkishness - culture (kültür), ancestry (soy) and race (rrk). ${ }^{13}$ Under the Settlement Law, non-Muslims were legally prohibited from applying for muhacir status which entailed aid schemes, an automatic and rapid naturalization procedure and tax exemptions. So, even if non-Muslims came from Ottoman territories, they could only be classed as "temporary guests." ${ }^{14}$ On the other hand, Muslim migrants from the Balkans and the Caucasus benefitted from several reception and assistance regimes.

The language practices of the newcomers were, however, sometimes marked as a criterion of otherness. During the single party period of Cumhuriyet Halk Partisi (Republican People's Party) between 1923-1946, some members of the public administration committee wrote comprehensive reports on "nations and nationalities" (millet ve milliyetler) in Turkey ${ }^{15}$ in order to provide recommendations on the administration of certain populations. These assessments and recommendations were formulated mostly according to their evident renunciation of prior communitarian features and mother tongues. Kemalist scholars also organized public campaigns such as "Vatandaş Türkçe Konuş" (Citizen, Speak Turkish), aimed at preventing the practice of non-Turkish languages; such campaigns found support too in the Kemalist and Democrat governments during the 1930s and 1960s. ${ }^{16}$ From any number of governmental campaigns and public pressure, Balkan Muslim populations and their descendants faced systematic assimilation and abandonment of their mother tongue, ${ }^{17}$ because even the use of dialects or impartial knowledge of Turkish could also be perceived as a sign of otherness. ${ }^{18}$ However, the early government reports also showed 
that non-Turkish speaking Balkan Muslim populations such as Albanians, Bosniaks and Pomaks ${ }^{19}$ were viewed in favorable terms: these migrants, it was said, understood the benefits of their children's assimilation into Turkishness and had forgone their community's distinctiveness. Nearly a century later, during my interviews, knowledge of Turkish and the non-transmission of other family languages (such as Albanian or Macedonian) were given as proof of loyalty and as acknowledgement of Turkish national values. For those who identified as evlad-ı fatihan, these aspects of family biography demonstrated the measure of their integration and legitimation within Turkish society.

\section{Emigration from Rumelia: mobilizing the history of conquest and dismemberment}

11 Evlad-ı fatihan, as a term, can be traced back to the thirteenth century, when it was used only in the Rumelian context. It "was the name given to those Anatolian Turks who were transported and settled with their families to Rumelia after the Ottoman conquest." ${ }^{20}$ The name first carried ethnic and social connotations because those who were transported to Rumelia were nomad (yörük) and semi-nomad (Tatar) tribes. ${ }^{21}$ Gradually, the ethnic associations became less important: "they were seen as Turkish by the Ottoman elite" but still referred to as "sons of the conquerors" because they represented "an ancient militia organization and [still] served under their own officers and regulations." ${ }^{22}$ Evlad-ı fatihan continued to be organized as militias from the seventeenth to the nineteenth centuries, ${ }^{23}$ and were also exempted from taxes. ${ }^{24}$ Furthermore, they served as regiment soldiers in the beginning of the nineteenth century, during the rule of Mahmud II who wanted to re-organize the fatihan into a new army. He wanted to replace the janissaries who were abolished in 1826 with the fatihan, but the regiment of fatihan was also disbanded after $1846 .{ }^{25}$ In the late nineteenth century, following the Russian-Turkish War of 1878 and the loss of lands in Rumelia, "the Muslim intelligentsia in the Balkans began to attach a special importance to the role of their region in the establishment and then the expansion of the Ottoman Empire into Anatolia and the Middle East." ${ }^{26}$ It was around this time that the term evlad-l fatihan acquired a symbolic significance so as to represent the defenders of the Ottoman legacy. Kemal Karpat suggests that the institutional representation had therefore unavoidably shifted towards a Muslim and Ottomanist one. Turkish intellectuals and politicians continued to use this term in the 1930s, and from that point on it designated "Rumelia's Muslim Turks." 27

Turkishness and Muslimness were, however, interchangeable in the Rumelian context. Until the 1940s, the terms, "Turkish" and "Muslim", were in fact used simultaneously to designate Balkan immigrants. ${ }^{28}$ Hakan Erdem quotes the memoirs of Riza Nur, the second Turkish delegate to the Lausanne Conference of 1932, who "claims [...] that he did his best to ensure a population exchange between Greece and Turkey on ethnic as well as religious grounds [...] [and] that Albanians of Janina (Ioannina) managed to immigrate to Turkey saying 'We are Turks, we are Evlad-ı Fatihan." ${ }^{29}$ Nur's memoirs could let us presume that the denomination was already in use in the Balkans during the 1920s, but, other than his memoirs, no source shows the scale of its usage in the public space in the early twentieth century. 

references in order to claim a Turkish and Muslim identity. It is used to distinguish ideal immigrants (who conform to the imagined Turkish community) from immigrants who remain outsiders. Its usage therefore highlights a Muslim religious affiliation, as well as a declared genealogy to the earliest evlad-ı fatihan in Rumelia. In Gostivarlılar Derneği, where I started to conduct my research on evlad-ı fatihan, those who were from Muslim Albanian-speaking families would emphasize the fluidity of Muslimness and Turkishness to prove their conformity with the Turkish community. However their membership to the group passed through the idea of sacrifice. Some interviewees, who appropriated evlad-ı fatihan as an identity marker, use their family's recent migration history to emphasize the sacrifices that their parents or their grandparents made to preserve the religious identity of the family. These claims preserve references to the identification began by the first generation of immigrants when constructing their Muslim credentials and therefore their so-called Turkish ascendance.

ost interviewees, however, spoke of a double sacrifice in their long family histories. The first sacrifice had occurred when the evlad-ı fatihan, leaving the safe lands of Anatolia to spread the faith and Islamic-Turkish rule. For the sake of converting the "infidels," they had mixed with the local population in Rumelia, forgone their language and part of their culture - but never their religion. The second sacrifice was to leave all - land, homes, even cemeteries - to return, centuries later, to the motherland, Turkey, with the only hope to be greeted as "distant cousins." This narrative positions Islam as the central reason for mobility as it claims that these populations allegedly moved to Rumelia for proselytism and later returned to the Turkish Republic to preserve their faith. This narration helps to replace their otherness ("distant cousins") with a performance of conformity and to justify the adoption of other languages as a necessary component of religious and imperial service. ${ }^{30}$

Certainly some families in Turkey are genealogically tied to the evlad-ı fatihan militias. Heath Lowry and İsmail Erünsal show, for example, that the Hacı Evrenos from Yenice-i Vardar (today's Yannitsa in Greece), who took on derived surnames such as Evrenos, Evrenosoğlu or Gazievrenosoğlu on the basis of the 1934 Law on Surnames, can be connected to lineages in a late-seventeenth century şecere (genealogical tree). ${ }^{31}$ The usage of some other surnames also demonstrates a genealogical affiliation to the evlad- 1 fatihan and, as Olivier Bouquet argues, their continuous usage provides a way to "remember the ancestors" and "tie the binds" to a certain history. ${ }^{32}$ However, the vast majority of the populations of Balkan origin who have since appropriated the label evlad-l fatihan do not possess a demonstrable genealogical tie to the historic militia forces. The narrative, rather, is linked to an anachronistic interpretation of the Ottoman past and to an imagined ethnicity drawn from imperial geography.

\section{Identification through (symbolic) space}

The first migrant homeland associations (göçmen dernekleri) were founded between 1946 and 1950. State financial assistance to immigrants considerably decreased from 1930 due to the financial crash; throughout the 1940s it continued to decrease, and the schemes disappeared de facto after the second World War. Nevertheless mass migrations from the Balkans resulted in around 200,000 naturalized Balkan Muslims in Turkey from the war until the $1960 \mathrm{~s} .{ }^{33}$ As this period was marked further by economic 
depression, serbest göçmen arriving in the middle and later decades of the twentieth century found much-needed resettlement assistance in the homeland associations.

Unlike iskanl, serbest göçmen could not benefit from state settlement aid schemes. Muslim Balkan populations who migrated to Turkey after the Second World War could migrate only as serbest. This is reflected in the narrative of one of the interviewees, Fatih, born in 1955 in Yugoslavia. He migrated in 1957 to Çorlu and then to Istanbul with his Turkish-speaking father and Albanian-speaking mother. He remembered that his parents had to have a vesika (testimonial) that stipulated that they would not ask for financial support from Turkey and that they would relocate as serbest. ${ }^{34}$ Similar types of documents can also be found in the diplomatic archives in Turkey. Several heads of families signed between 1949 and 1959 a taahhüt senedi (certificate of obligation) at the Turkish General Consulate in Skopje certifying that they intended to migrate as serbest and would not ask for help from the Turkish government or Turkish public officers.

\section{Institutionalized kinship networks}

Homeland associations were founded in this context by migrants from earlier periods. They were meant to help newcomers, particularly in large cities such as Istanbul, Ankara and Bursa. They emerged out of pre-existing logistic networks and were linked, as Alexandre Toumarkine stated in his article on homeland associations, to the urban settlement areas of immigrants who had also immigrated without an aid plan from the mid-1930s. ${ }^{35}$ The associations founded after the Second World War proposed aid for immigrants who had obtained the status of serbest, but who had not the means to settle in Turkey.

From 1946 until 2003, 166 Balkan migrants' homeland associations (Balkan göçmen dernekleri) were founded. In addition to implementing aid schemes, these associations were also instrumentalized to promote pan-Turkism, even though their members were not all Turkish-speaking populations. And, in the context of the Cold War, these associations also served as agents of anti-communist propaganda, spreading allegations about the mistreatment of Muslims in socialist Yugoslavia, Romania and Bulgaria. ${ }^{36}$

From the late 1940s, the term göçmen (migrant) replaced muhacir as a legal status. The new term was incorporated into the name of several associations, but its use alone reveals nothing more about the ethno-confessional identities of those who joined them nor about their dominant patterns for integration. More is revealed by the locational name attached to these associations. This is because Balkan emigration to Turkey was based on local and family networks; in return migrant networks (then associations) linked back to places of origin. The associations institutionalized an affective bond that is called hemşehrilik (being of the same country/town), and my interviewees often explained hemşehrilik as a type of kinship that enables the integration of newcomers into local community. Over time, these associations developed a common discourse on national and regional identifications, and a will to keep a body of cultural and historical narrative alive, with references to Rumelia, Turkishness and mobility. The sons of those who immigrated to Turkey between the 1940s and 1960s developed the discourse on evlad-ı fatihan precisely in this contextual associative space. 


\section{Assertion of fatherland's value}

21

Evlad-l fatihan frames space in two ways: firstly through the immigration to Turkey in the twentieth century and secondly through the supposed emigration from Anatolia to Rumelia after the thirteenth century. The meaning of migration and return is therefore highly relative and these two interpretations of space define the idea of conquest in both ways. This implements an intertwinement of what would be motherland (Turkey) and fatherland (Balkan lands).

They called us gavur (non-Muslim, infidel), because we weren't speaking Turkish and our language didn't have Arabic sonorities. Some among us [Balkan postmigrants] decided then to call themselves evlad-ı fatihan, because they wanted to show to others that we were more Turkish than the rest who were coming from the East of Turkey [to Istanbul] and that we were the legitimate successors of our Turkish lands. ${ }^{37}$

The first pillar of the identification through space is through the "conquest" of Istanbul or Bursa, where there is a high number of migrations from the Balkans, which were primarily enlarged by rural depopulation after 1950s. Calling one's self evlad-ı fatihan does not only claim a Balkan ancestry, but also a reference to conformity. It allows those who appropriate it to claim that they are less an outsider than other groups of populations in Istanbul and to differentiate themselves from the rural exodus. Furthermore, it could be argued that since nearly every Anatolian inhabitant of Istanbul or Bursa could refer to a village or town of origin inside the anavatan (motherland), the Balkan post-migrants were urged to invest in their own heritage even though they had no spatial and cultural knowledge or links to the first generation's place of origin.

The investment is however linked to the idea of building a bridge between memleket (fatherland) and anavatan (motherland), ${ }^{38}$ which seems to be the second interpretation of the space. As Ayça Kurtoğlu proposes, the place of origin, fatherland, is memleket, referring to the "inherited" lands of the forefathers, as opposed to anavatan, which is the motherland. Memleket and anavatan are not commutable, but they exist alongside each other. Members of associations who appropriate evlad-l fatihan often assigned more value to memleket than to anavatan in the Ottoman political context. Interlocutors in these associations mostly emphasize Rumelia's significance for the Ottoman Empire in comparison with Anatolia during the first centuries of its expansion policies. They further argue that the dethronement of Abdülhamid II after the upheaval in Rumelia in 1908, and the weakening of the Ottoman Empire after its losses in Rumelia show how crucial their Balkan homelands were for the empire. This narrative also claims that Rumelia was also important for the Young Turks, many of whom came from these territories. ${ }^{39}$ This narrative places the Balkans in the center of late Ottoman history and hence constitutes a strong political atmosphere for the nostalgia surrounding memleket. Furthermore, associations such as Rumeli Türkleri Derneği (Association of Rumelian Turks) have hung several portraits of famous Ottoman intellectual figures from the Balkans alongside Atatürk's: Mehmet Akif Ersoy, Yahya Kemal and şemsettin Sami (Frashëri) in a demonstration of Rumelian contributions to Turkish culture and society. These representations are further mobilized to show double identities, as one could presumably be an "Albanian" and serve the interest of Turkish society. This perception implies again the idea of being neither a foreigner nor peripheral.

Balkanologie, Vol. $16 n^{\circ} 1 \mid 2021$ 

migrants has shaped the historical narrative on Balkan immigration itself. For example,
the April 1999 issue of Evlad-ı Fatihan included an article by Mehmet Koca, one of the founders of the Western Thracian Association. The text, entitled "In the Light of History: Yesterday's Greek, Today's Kosovo migrants," addresses the duality of anavatan
and memleket as an issue of loyalty. The article starts with an allegory comparing the
mother-child relationship to the relationship between Turkey and Rumelian Turks. The
history of Turks settling in Rumelia and their "return" to anavatan is represented so
that it emphasizes how the post-1878 migrations were easily accepted by society and by
the state, "even though their children (sons of conquerors) spoke another language."
The author lists in common groups, different waves of migrations of Muslim Balkans: History: Yesterday's Greek, Today's Kosovo migrants," addresses the duality of anavatan
and memleket as an issue of loyalty. The article starts with an allegory comparing the
mother-child relationship to the relationship between Turkey and Rumelian Turks. The
history of Turks settling in Rumelia and their "return" to anavatan is represented so
that it emphasizes how the post-1878 migrations were easily accepted by society and by
the state, "even though their children (sons of conquerors) spoke another language."
The author lists in common groups, different waves of migrations of Muslim Balkans: History: Yesterday's Greek, Today's Kosovo migrants," addresses the duality of anavatan
and memleket as an issue of loyalty. The article starts with an allegory comparing the
mother-child relationship to the relationship between Turkey and Rumelian Turks. The
history of Turks settling in Rumelia and their "return" to anavatan is represented so
that it emphasizes how the post-1878 migrations were easily accepted by society and by
the state, "even though their children (sons of conquerors) spoke another language."
The author lists in common groups, different waves of migrations of Muslim Balkans: History: Yesterday's Greek, Today's Kosovo migrants," addresses the duality of anavatan
and memleket as an issue of loyalty. The article starts with an allegory comparing the
mother-child relationship to the relationship between Turkey and Rumelian Turks. The
history of Turks settling in Rumelia and their "return" to anavatan is represented so
that it emphasizes how the post-1878 migrations were easily accepted by society and by
the state, "even though their children (sons of conquerors) spoke another language."
The author lists in common groups, different waves of migrations of Muslim Balkans: History: Yesterday's Greek, Today's Kosovo migrants," addresses the duality of anavatan
and memleket as an issue of loyalty. The article starts with an allegory comparing the
mother-child relationship to the relationship between Turkey and Rumelian Turks. The
history of Turks settling in Rumelia and their "return" to anavatan is represented so
that it emphasizes how the post-1878 migrations were easily accepted by society and by
the state, "even though their children (sons of conquerors) spoke another language."
The author lists in common groups, different waves of migrations of Muslim Balkans: History: Yesterday's Greek, Today's Kosovo migrants," addresses the duality of anavatan
and memleket as an issue of loyalty. The article starts with an allegory comparing the
mother-child relationship to the relationship between Turkey and Rumelian Turks. The
history of Turks settling in Rumelia and their "return" to anavatan is represented so
that it emphasizes how the post-1878 migrations were easily accepted by society and by
the state, "even though their children (sons of conquerors) spoke another language."
The author lists in common groups, different waves of migrations of Muslim Balkans: History: Yesterday's Greek, Today's Kosovo migrants," addresses the duality of anavatan
and memleket as an issue of loyalty. The article starts with an allegory comparing the
mother-child relationship to the relationship between Turkey and Rumelian Turks. The
history of Turks settling in Rumelia and their "return" to anavatan is represented so
that it emphasizes how the post-1878 migrations were easily accepted by society and by
the state, "even though their children (sons of conquerors) spoke another language."
The author lists in common groups, different waves of migrations of Muslim Balkans: In most of the homeland associations of Istanbul, one could notice various forms of the
quotation from Mustafa Kemal [Atatürk]'s statement of 1931, "Migrants are the holy memories of lost lands" (Muhacirler kaybedilmiş toprakların aziz hatıralarıdır), carved on a wooden frame or printed with a picture of him hung on the wall. The display of this rmula could be interpreted as a way to demonstrate their importance for
epublican governments and that migration from the Balkans was indeed wanted.

We are representing all the migrants from Rumelia and their children, and we certainly see ourselves, and people like us as evlad-ı fatihan because we are from the same memleket and [are] the true protectors of the lost lands. ${ }^{40}$ designation of evlad-ı fatihan to "all the migrants from Rumelia." In almost all other
above quote, Sinem, the porte-parole of the Rumeli Türkleri Dernegi ${ }^{41}$ extends the uses, however, this is a gendered label; it is used by and for men because its links to (from Rumelia), which evoke only a legal status or place of origin. 
They came from the islands, from Bulgaria, from Greece. They came from the East and the West. They came again and again. They came as migrants (göçmen), as refugees (mülteci), as independent (serbest), as fugitives (kaçak). Motherland always received them with open arms. ${ }^{44}$ nostalgia for a post-imperial identification. The discourse on this bond plays a reconciliatory role regarding existing resentments concerning the post-Ottoman status of former territories. The dialectic between Rumelia and Turkey is not only represented in the form of sacrifice and trajectories, but also through the usage of pronouns such as "ours" and "theirs." For instance, the January 1999 issue tells the story of the Ottoman imperial conquest of the Balkans and, relatedly, the evlad-l fatihan, with two maps of the Balkans inserted showing "our provinces once upon a time" and "Turkey once upon a time," to stress that more Turks used to live in Rumelia than in Anatolia. Firstly, in their published letters sent to the magazine's editorial board, readers mobilize the image of Ottoman Rumelia. In 1999, a Turkish reader from Western Thrace, Ali Genç, sent, in the Ottoman alphabet, a letter of condolences after the earthquake of 17 August that hit the region of Marmara, in which he also expressed his gratefulness vis-à-vis the magazine. The magazine published the letter's translation in their "Letter to Evlad-ı Fatihan" (Evlad-ı Fatihan'a Mektuplar) section together with the original copy in Ottoman and the following introduction: "Our letter of the month is again from Western Thrace. Again written in Ottoman. If we didn't know Ottoman, these Western Thracians would make us spend a lot of money for translations!" 46 Ottoman as a chosen tool of communication shows how Balkan territories and the Muslim and Turkish presence therein are evoked through Ottoman nostalgia. The imperial past hence becomes intertwined with the Republican present.

Secondly, the magazine includes a "Young Writers" section, where so-called young students publish their poems about the war in Kosovo or about other aspects of their grandparents' hometowns. The following poem gives an example of the imaginary of the Balkans linked with the Ottoman heritage:

The beautiful city embellishing my dreams,

Land of my grandfather, relic of my forefathers

I'm craving to see you

I want, at least once, to come to you. 
You are an old Turkish land,

Conquered by Murat the God-loved Sultan, ${ }^{47}$

Where lie evlad-ı fatihan,

Where they look back now with deep sorrow.

I always imagined myself on Fatih Bridge

Listened to your local songs captivated

Washed my face from your decorated fountains

Which opened my rusted eyes

I here burn with your love

I wish to join you SKOPJE!

Your name embellishes my prayers

My heart beats differently with you.

If ever [it has] been written for me to reach you one day

I'll rub my face to your soil,

My emotions will flood and overflow

Then sentences neither will nor are able to translate my feelings. ${ }^{48}$ Rumelia and memleket. The usage of historical references in the second verse could also exhibit Skopje as a symbolic bastion of Turkishness. The author's invocation of Fatih Bridge of Skopje may also reinforce the idea of interconnectivity and loss of the territory. This poem stresses the phenomenon of hemşehrilik as the discursive and associative identifications are articulated in the social and territorial order. The "Young Writers" section of the magazine is therefore a space for reinforcing the connection of post-migrants to their parents' or grandparents' spatial references in the Balkans.

The marker evlad-l fatihan is, in fact, the magazine's primary strategy to strengthen or create connections. The monthly section "According to Us" includes multiple political articles regarding Cyprus or the "Armenian Issue," in which contributors and editors stress their role as true saviors and defenders of Turkishness and Islam. In 2000, for instance, an editorial on the Eurasian Islam Council's meeting, on 24 and $25 \mathrm{July}$, stated: "The most efficient and easiest way to be influential in the Balkan countries for Muslims is through religious services." ${ }^{49}$ It further remarks that in every Balkan country there are Muslim populations, concludes that "most of these populations are Turkish, therefore evlad-ı fatihan," and specifies that those who are not from a demonstrably Turkish lineage are nevertheless linked to Turkey through strong denominators such as religion and Ottoman heritage. The article also suggests that Turkey must be the pillar for Balkan Muslims' religious affiliations and continue to provide moral support to those populations. The issue of Islam is therefore used as a negotiation tool to create connectivity between memleket and anavatan.

\section{Conclusion}

Evlad- 1 fatihan is an invented tradition which marks a set of vocabulary and practices to demonstrate a belonging to the norms of Turkish national identity. It is only used in the public space as either an individual or a collective marker by Balkan post-migrants, and constructed through genealogy, mobility and territory. These three components are modeled through evlad- $\iota$ fatihan to reinforce the identification process of migrant and post-migrant Balkan populations in Turkey. Therefore, it is neither created nor documented as a state categorization, but as an integration strategy. Through this 
process, those who sought to be called evlad-l fatihan would be seen as conformist beings in the public space.

Evlad- 1 fatihan is however not a label used by every Muslim Balkan migrant or postmigrant. It is first and foremost a masculine label used only by and for men. It is also a term that draws specific associations with Islam and Ottoman conquest, not only as forms of identity, but through militarized sacrifice and martyrdom. Consequently, men who claim to be secular (laik) rarely used this denomination. Further research on the correlation between masculinity and denominations could give some nuanced answers regarding membership and identification processes. Moreover, evlad-l fatihan represents an Ottomanized perception of space which is not shared by all Balkan migrants and post-migrants. Some of the homeland associations such as the YugoslavyaKaradağ Göçmenleri Sosyal Dayanışma ve Kültür Derneği (Yugoslavian-Montenegrin Immigrants' Social Solidarity and Culture Association) prefer grouping Muslim Balkan migrants and post-migrants according to a post-Yugoslav perception of space, praising the cultural and linguistic diversity of the former Yugoslav region. Still other groups have changed their relationship to political demarcations of space within the Balkans. One such group is the Gostivarllar Derneği. They offered Macedonian and Albanian language lessons to post-migrants until 2012, but then decided to offer only Ottoman language courses; this is because they identify themselves more with the Ottoman heritage than with other community features. So, though evlad-l fatihan is not a label that every (post-)migrant appropriates, it could still be a form of national and linguistic categorization and thus have an outcome on identification processes in the postimperial space of the Republic of Turkey.

The appropriation of the term has gained momentum in recent years and juxtaposes itself with the neo-Ottomanism that has become one of the positions leading foreign affairs in Turkey. A study on the relationship between the appropriation of evlad-l fatihan and neo-Ottomanism could expand our knowledge on negotiations between Turkey and the Turkish and Muslim populations in the Balkan states such as Bosnia, Macedonia and Bulgaria.

Those who proclaim to be evlad-ı fatihan invoke an invented tradition that explains how religion and descent renders as natural and unquestionable, the loyalty of Balkan postmigrants to the Republic of Turkey. Indeed, the associative space allows Balkan migrants and post-migrants to re-interpret the history of Balkan emigration to Turkey. Consequently, these associations and those who have appropriated this label perform their identification in regard to memleket and anavatan to centralize their importance for the safeguard of Turkish national identity, and to show that they are not newcomers, but in their rightful place in the Turkish Republic. Its appropriation therefore proclaims a dual "we" through multiple categorizations evoked by the Republican policies which led to the identification of a loyalty that is concurrently mobilized by the post-migrants born into families that immigrated to Turkey in the twentieth century. It is therefore a result of negotiations in the public space on social and cultural appropriations that can be described from and through conformity and otherness. 


\section{NOTES}

1. This article benefited from the generous contribution of the 2015 KOSMOS Summer University Phantom Borders - Real Boundaries and POLTUR funded by the Émergence(s) program of Ville de Paris. I would like to thank Marc Aymes, Petra Bakos, Dana Dolghin, Gabriel Doyle, Andreas Guidi, Özgür Türesay and Nicolas Vatin for their comments and suggestions. I am also grateful to Guillaume Javourez for his help and support.

2. The association was founded in 1974.

3. See KIRIsçI Kemal, «Disaggregating Turkish Citizenship and Immigration Practices », Middle Eastern Studies, 2000, vol. 36, $\mathrm{n}^{\circ}$ 3, p. 15.

4. All the interviewees were born during the 1940s-1960s to parents who had already migrated to Istanbul, or who did so when the interviewees were children. Their parents were classed administratively as serbest göçmen (lit. independent migrants), and did not benefit from settlement assistance or aid schemes. The interviewees joined homeland associations in their twenties or thirties to "discover family heritage." Participant observation was undertaken in the following Balkan homeland associations in Istanbul between June 2013 and September 2015: Gostivarllar Derneği in Alibeyköy; Rumeli Türkleri Derneği in Aksaray; Prizrenliler Derneği and Yugoslavya-Karadağ Göçmenleri Sosyal Dayanışma ve Kültür Derneği in Bayrampaşa. The same technique was also used in Rumeli Balkan Federasyonu in Haseki, Istanbul.

5. This paper employs the term "post-migrant" to define individuals who were young children at the time of migration, or as per interviewees, born in the host country into migrant families after the migration has occurred.

6. For a broad discussion on identification see AKTÜRK Şener, "Persistence of the Islamic Millet as an Ottoman Legacy: Mono-Religious and Anti-Ethnic Definition of Turkish Nationhood," Middle Eastern Studies, vol. 45, n 6, 2009, p. 893-909; ÇAĞAPTAY Soner, Islam, Secularism, and Nationalism in Modern Turkey: Who is a Turk?, London, Routledge, 2006; KIRISÇı Kemal, "Disaggregating Turkish Citizenship”, op. cit, p.1-22; NEYZI Leyla, “Ben Kimim?”: Türkiye’de Sözlü Tarih, Kimlik ve Öznellik [“Who am I?": Oral History, Identity and Subjectivity in Turkey], Istanbul, İletişim Yayınları, 2013 [2004]; YEĞEN Mesut, Müstakbel Türk'ten Sözde Vatandaşa: Cumhuriyet ve Kürtler [From Potential Turk to Alleged Citizen: The Republic and the Kurds], Istanbul, İletişim Yayınları, 2006.

7. Also referred to as Turkey of Europe, it corresponds to today's Balkans.

8. новSваWм Eric J. et al. (ed.), The Invention of Tradition, Cambridge, Cambridge University Press, 1983, p. 2.

9. Ibid., p. 7.

10. BALKACIOĞLU Nurcan Özgür, Dış politika ve Göç: Yugoslavya'dan Türkiye'ye Göçlerde Arnavutlar (1920-1990) [Foreign Policy and Migration: The Albanians during the Migrations from Yugoslavia to Turkey (1920-1990)], Istanbul, Derin Yayınlar1, 2010, p. 409.

11. While the echo of the biography of Muhammad and his companions can be heard in the term muhacir, because it applies to Muslims who traveled from Mecca to Medina, the emphasis is less on the religious allusion than on the idea of departure and migration to the regressing Ottoman territories, which is also reflected in the historiography on forced displacements of the nineteenth century. The muhacir are defined either as refugees or as immigrants who move because of the new territorial order. See Popovic Alexandre, L'Islam balkanique: les musulmans du sud-est européen dans la période post-ottomane, Istanbul, Isis, 2009, p. 70.

12. See ÜLKER Erol, "Assimilation, Security and Geographical Nationalization in Interwar Turkey: The Settlement Law of 1934," European Journal of Turkish Studies, $\mathrm{n}^{\circ} 7,2008$, online: http:// journals.openedition.org/ejts/2123 (accessed in July 2021). 
13. See DANIş Didem, PARLA Ayşe, "Nafile Soydaşlık: Irak ve Bulgaristan Türkleri Örneğinde Göçmen, Dernek ve Devlet" [Kinship in Vain: Immigrants, Association and State in the Case of Iraqi and Bulgarian Turks], Toplum ve Bilim, vol. 114, 2009, p. 131-158.

14. ÖZTÜRK Neva Övünç, Mültecinin Hukukî Statüsünün Belirlenmesi [Defining the Legal Status of Refugees], Istanbul, Seçkin Yayıncılık, 2015, p. 393.

15. BCA 490.0.1.0/61.233.6: Kars mebusu Cevat Dursunoğlu'nun Türkiye'deki azınlıklara ait bir araştırması (27.03.1944). [A research made on minorities in Turkey by member of parliament for Kars Cevat Dursunoğlu] Archival Funds (Başbakanlık Arşivi, Ankara): BCA 490.1.0.0 Cumhuriyet Halk Partisi (People's Republican Party).

16. See ASLAN Senem, "'Citizen, Speak Turkish!': A Nation in the Making," Nationalism and Ethnic Politics, vol. 13, n², 2007, p. 245-272.

17. See BECAN Elif, "Structuring Migrants at the Local Level: Neighborhood and the Language Practices of Second-Generation Albanians in Post-Ottoman Turkey (1930-1960)," Irish Slavonic Studies, vol. 26, 2017, p. 1-24 (7-8).

18. TRIX Frances, Urban Muslim Migrants in Istanbul: Identity and Trauma among Balkan Immigrants, London, I.B. Tauris, 2017, p. 126.

19. The report written by Cevat Dursunoğlu separates for instance the Muslim Migrants into two: "Muslim fellow citizens whose mother tongues are not Turkish but living discretely and dispersed alongside the Turkish community" (Anadilleri ayrı olup Türk camiası içinde dağınık ve münferit bir surette yaşayan Müslüman Yurddaşlar) and "Muslim fellow citizens whose mother tongues are not Turkish and living in small communities" (Anadilleri Türkçeden başka olan ve küçük topluluklar halinde yaşayan Müslim Yurddaşlar). See BCA 490.0.1.0/61.233.6, p. 20-22.

20. PAKALIN Mehmet Zeki, "Evlad-1 fatihan," in Osmanlı Tarih Deyimleri ve Terimleri Sözlüğü [Dictionary of Terms and Expressions of Ottoman History], vol. 1, Istanbul, Milli Eğitim Basımevi, 1993, p. 571-572.

21. See Gökbilgin M. Tayyib, Rumeli'de Yürükler, Tatarlar ve Evlâd-1 Fâtihân [The Yörük, Tatars and Evlâd-1 Fâtihân in Rumelia], Istanbul, Osman Yalçın Matbaası, 1957, p. 253-312.

22. ERDEM Hakan, "Turks as Soldiers in Mahmud II's Army: Turning the Evlad-1 Fatihan into Regulars in the Ottoman Balkans," in Sabine Rutar (ed.), Beyond the Balkans: Towards an Inclusive History of Southeastern Europe, Zürich, Lit, 2014, p. 227-246 (231).

23. Gökbilgin, Rumeli'de Yürükler, op. cit., p. 253.

24. ERDEM, "Turks as Soldiers," op. cit., p. 232.

25. ERDEM, "Turks as Soldiers," op. cit., p. 241.

26. KARPAT Kemal, The Politicization of Islam Reconstructing Identity, State, Faith, and Community in the Late Ottoman State, Oxford, Oxford University Press, 2001, p. 342.

27. ERDEM, "Turks as Soldiers," op. cit., p. 231.

28. See CLAYER Nathalie, Aux origines du nationalisme albanais. La naissance d'une nation majoritairement musulmane en Europe, Paris, Karthala, 2007, p. 43.

29. ERDEM, "Turks as Soldiers," op. cit., p. 242.

30. However, this narrative shouldn't be taken literally. See BAER Marc David, Honored by the Glory of Islam: Conversion and Conquest in Ottoman Europe, Oxford, Oxford University Press, 2007.

31. LOWRY Heath W. et al., "The Evrenos Dynasty of Yenice Vardar : Notes and Documents on Haci Evrenos and the Evrenosoğulları: A Newly Discovered Late-17th Century şecere (Genealogical Tree), Seven Inscriptions on Stone and Family Photographs," The Journal of Ottoman Studies, vol. 32, 2008, p. 9-192 (12).

32. BOUQUET Olivier, Les noblesses du nom : essai d'anthroponymie ottomane, Turnhout, Brepols, 2013, p. 234-235.

33. The number of immigrants during the Second World War is calculated throughout the naturalization dossiers by including those who were naturalized collectively between 6 January 
1939 and 18 January 1960. See collective naturalization dossiers on Direction of the Decisions Department of Cabinet of Ministers (BCA 30.18.1.2), Ankara.

34. Fatih, personal interview, 20 September 2015. This interviewee was actively involved in Rumeli Balkan Federasyonu. The interview addressed questions of administrative procedures put in place for muhacir and/or göçmen status and homeland associations aid strategies.

35. TOUMARKINE Alexandre, "Le développement des associations de hemşehri en Turquie (19332003) à l'échelle nationale et départementale," European Journal of Turkish Studies, $n^{\circ} 2,2005$, § 13, online: http://journals.openedition.org/ejts/409.

36. Ibid., $\S 12$.

37. Hasan (b. 1957), personal interview, 17 July 2014. This interviewee was a representative of Yugoslavya - Karadağ Göçmenleri Sosyal Dayanışma ve Kültür Derneği. The interview addressed questions of post-socialist solidarity among Yugoslav migrants in Istanbul; Rumelia as a social and territorial fabric; and the relationship between language and national identities.

38. See Kurtoğlu Ayça, Hemşehrilik ve şehirde Siyaset: Keçiören Örneği [Being from the Same Country and Politics in the City: The example of Keçiören], Istanbul, İletişim, 2004, p. 143-256.

39. For the relationship between some Young Turks' individual trajectories and their political agendas see zÜRCHER Erik Jan, “The Young Turks - Children of the Borderlands?," International Journal of Turkish Studies, vol. 9, $\mathrm{n}^{\circ}$ 1-2, 2003, p. 275-286.

40. Sinem (b. 1963), representative of Rumeli Türkleri Derneği, interview conducted on 16 October 2014, Istanbul. The interview addressed the association's activities throughout the twentieth century.

41. The logo of Rumeli Türkleri Derneği provides a good example of the masculinized and militarized aspects evlad- $\iota$ fatihan. It consists of an Ottoman horseman holding the green flag with three crescents, representing the three continents ruled by the Ottoman Empire.

42. Evlad-ı Fatihan, February issue, 1999, p. 5.

43. Ibid.

44. Evlad-1 Fatihan, April issue, 1999, p. 5-6.

45. This is the narrative of the magazine's editorial board. Kosovar refugees who came to Turkey during the conflict were, however, neither seen nor presented as Turks returning home by state officials. This discourse was also not interiorized by the refugees, since most returned to Kosovo out of obligation or choice. See içDUYGu Ahmet et al., "Globalization, Security, and Migration: The Case of Turkey," Global Governance, vol. 6, nº 3, 2000, p. 383-398.

46. Evlad-ı Fatihan, August issue, 1999, p. 28.

47. It was actually not under Murad the First, but under his successor Bayezid, that the Ottomans conquered Skopje. See IMBER Colin, Ottoman Empire 1300-1650: The Structure of Power, New York, Palgrave Macmillan, 2002, p. 37-54.

48. Hayallerimi süsleyen güzel şehir, Dedem memleketi, ecdat yadigârı. Hasretim seni görmeye; İstiyorum bir defa dahi olsa, sana gelmeye. / Sen ki, Murat Hüdavendigar'in açtı̆̆ı, Evlad-ı Fatihan'ların yattığı, Simdi ise hüzünle baktığı, Bir eski Türk diyarısın. / Hep hayal ettim kendimi Fatih Köprüsü’nde, Türkülerini dinledim kendimden geçercesine. Tuğralı çeşmelerinde yıkadım yüzümü, Seninle açtım bu paslanmış gözümü. / Ben burada sevginle yanıyor, Senin vuslatını istiyorum ÜSKÜP! Adın dualarımı süslüyor, Kalbim seninle daha hoş oluyor. / Bir gün gelmek nasip olursa sana, Yüzümü süreceğim toprağına. Duygularım sel olup taşacak, 0 zaman cümleler halini anlatamayacak. By Rakip Ertuğrul Eriz in Evlad-ı Fatihan, June issue, 1999, p. 31.

49. Evlad-1 Fatihan, August issue, 2000, p. 2. 


\section{ABSTRACTS}

This research aims to explore historical and spatial references conveyed by the term evladfatihan, a designation used in Balkan homeland associations in Turkey since the late 1980s. Drawing mostly on interviews conducted with members and directors of multiple homeland associations in Istanbul and also on observations made in these institutions between 2013 and 2015 , the study opens a discussion on how references to Ottoman heritage and to Islam were experienced and interpreted by the actors and investigates how the usage of evlad-l fatihan produced an anachronistic narrative of post-imperial migration and an "invented tradition."

Cette recherche vise à explorer les références historiques et spatiales véhiculées par le terme evlad-ı fatihan, une désignation utilisée dans les associations de pays des Balkans en Turquie depuis la fin des années 1980. En se fondant principalement sur des entretiens menés avec des membres et des directeurs de multiples associations de pays à Istanbul ainsi que sur des observations faites dans ces institutions entre 2013 et 2015, l'étude ouvre une discussion sur la façon dont les références à l'héritage ottoman et à l'islam ont été vécues et interprétées par les acteurs et étudie comment l'utilisation de evlad-ı fatihan comme étiquette a produit un récit anachronique de la migration post-impériale et est devenue une «tradition inventée ».

\section{INDEX}

Mots-clés: identification, associations de pays, immigration, Turquie contemporaine

Keywords: identification, homeland associations, immigration, contemporary Turkey

\section{AUTHOR}

ELIF BECAN

CETOBaC, Collège de France 